\title{
Damage detection in steel fiber reinforced concrete using resonant method
}

\author{
Neira Torić Malić, Natalija Bede, Ivica Kožar \\ University of Rijeka, Faculty of Civil Engineering
}

\begin{abstract}
Main aim of this work was to experimentally investigate steel fiber distribution in concrete, i.e. fiber segregation and nonuniform distribution, as well as possible internal cracks, with resonant frequency method (RFM). The RFM is based on determination of resonant frequencies of vibration on specimens excited by impact hammer, which is basis for determination of dynamic modulus of elasticity of FRC. Based on the reduction of dynamic modulus of elasticity and change of frequency response curve some conclusions about presence of local damage or defect are made. These conclusions are verified with $\mathrm{x}$-ray scans of FRC prisms.
\end{abstract}

Ključne riječi: steel fiber reinforced concrete, resonant frequency, impulse excitation method, dynamic modulus of elasticity

\section{Detekcija oštećenja u mikroarmiranom betonu primjenom rezonantne metode}

\section{Sažetak}

Cilj je rada primjenom metode rezonantne frekvencije (MRF) eksperimentalno proučiti raspored čeličnih vlakana u betonu, odnosno defekte nastale ugradnjom, kao što su segregacija i nehomogena raspodjela vlakana. Istražena je i mogućnost detekcije unutarnjih pukotina. MRF se zasniva na određivanju rezonantnih frekvencija uzoraka pobuđenih na vibracije udarnim čekićem, iz kojih se dalje određuje dinamički modul elastičnosti. Na osnovi redukcije dinamičkog modula elastičnosti i promjene oblika frekvencijske krivulje odgovora doneseni su zaključci o prisutnosti lokalnih oštećenja. Zaključci su potkrijepljeni rendgenskim slikama uzoraka.

Key words: beton armiran čeličnim vlaknima, mikroarmirani beton, rezonanatna frekvencija, metoda impulsne pobude, dinamički modul elastičnosti 


\section{Introduction}

Fiber reinforced concrete (FRC) as a high strength concrete is used in structures where superior mechanical properties to that of plain concrete are needed. It shows improved performance in cracking and shrinkage, as well as high ductility and tensile strength. However, there are also some drawbacks related to FRC. One of the major drawback is determination of fiber volume fraction as well as achievement of uniform distribution of fibers in the FRC mixtures. For example, as shown on Fig.1, non-uniform distribution can cause segregation in one side, which has as a consequence weak zone on the other side, with just a few fibers or even none. On the other hand, if fiber content is very high or fibers are too large, during concrete casting they can easily group into fiber balls and form areas only with fibers and air.

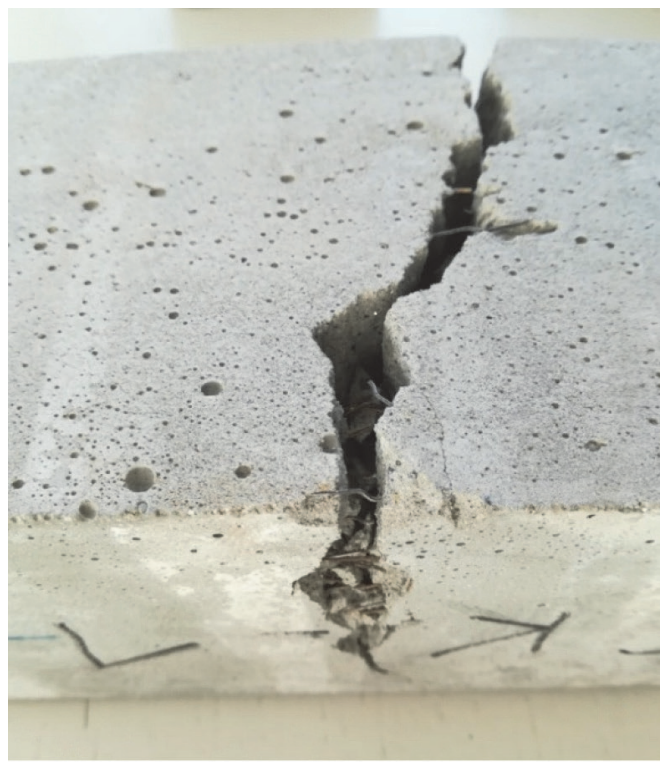

Figure 1. Steel fiber segregation in tensile zone of damaged beam

\section{Resonant frequency method}

In concrete testing non-destructive methods have very important role. The reason is that they are repetitive on the same specimen (structure) and enable application of other testing methods afterwards, because specimen remains undamaged. Over the past years many non-destructive methods developed such as surface hardness method, penetration resistance method, pull-out, brake-off test, pulse-echo, impact-echo method, ultrasonic pulse velocity method, resonant frequency method [1]. 
Unlike other above mentioned methods, resonant frequency method (RFM), it is not influenced by many factors, i.e. it is not dependent on moisture content, texture and surface smoothness, loading rate etc. [1],[2]. It depends only on specimen size and shape, and boundary conditions. Therefore, RFM is very fast and reliable. Also this method is very convenient for concrete structures, while for other materials different methods are used [3]. Hence, resonant frequency method [1] is used to obtain dynamic modulus of elasticity of FRC.

\subsection{Specimens geometry and dimensions}

All test specimens are prismatic beams with dimensions $100 \times 100 \times 400 \mathrm{~mm}$ as shown in Fig.2. Firstly, before testing each specimen, on the specimen surface grid with 15 nodes is drawn, to exactly determine position of accelerometers and impact points. Nodes along longer edge of the beam determine positions for accelerometers (Fig. 2 , nodes 1 to 5 , and 11 to 15 ), and nodes placed on the midline are nodes of impact application (Fig. 2, nodes 6 to 10).

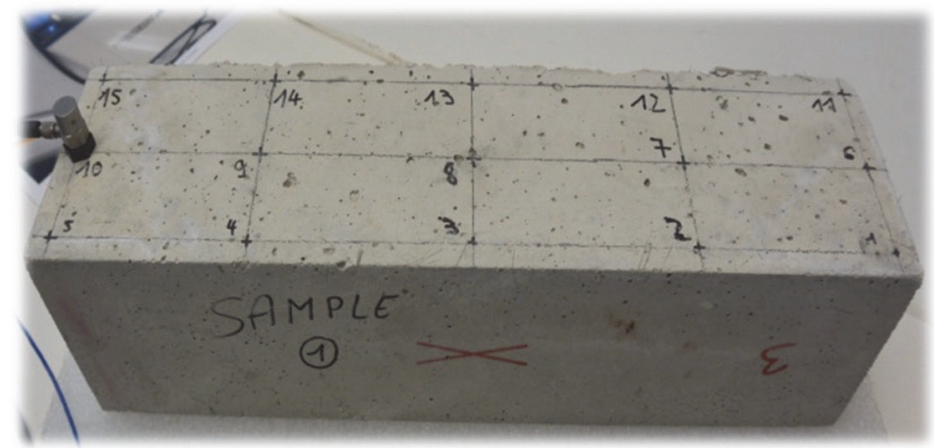

Figure 2. FRC prism specimen

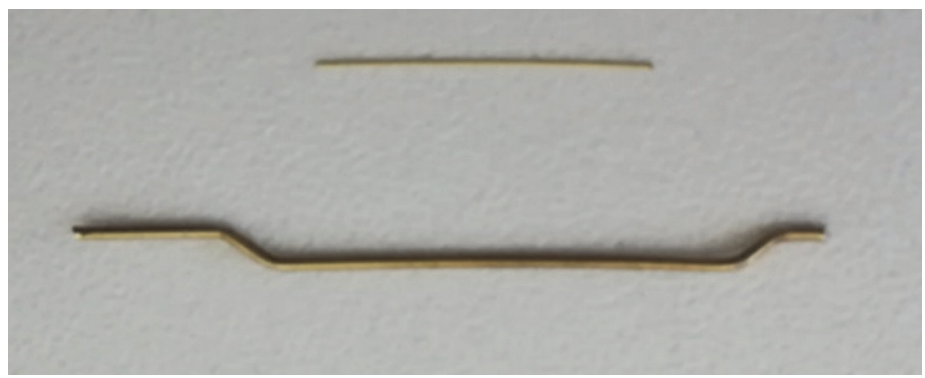

Figure 3. Steel fiber types used in specimens, up: $13 \mathrm{~mm}$ straight fibers; down: $30 \mathrm{~mm}$ hooked fibers

Specimens are made according to mixtures presented in Table 1. Two types of mixtures are used, marked as CM1 and CM2. Concrete mixtures CM1 and CM2 have the same constituents with the same portions except for the steel fibers. In CM1 are 
embedded short steel fibers of length $13 \mathrm{~mm}$ and diameter $0.2 \mathrm{~mm}$, while in $\mathrm{CM} 2$ long hooked steel fibers of length $30 \mathrm{~mm}$ and diameter $0.6 \mathrm{~mm}$, Fig.3. Further, in CM1 fiber content is higher $\left(200 \mathrm{~kg} / \mathrm{m}^{3}\right)$ than in CM2 (only $\left.78 \mathrm{~kg} / \mathrm{m}^{3}\right)$. More details can be found in [4],[3].

Table 1. Concrete mixture for FRC specimens

\begin{tabular}{|c|c|c|}
\hline & CM1 & CM2 \\
\hline Material & Content $\left[\mathrm{kg} / \mathrm{m}^{3}\right]$ & Content $\left[\mathrm{kg} / \mathrm{m}^{3}\right]$ \\
\hline Cement & 435.2 & 435.2 \\
\hline Silica fiume & 108.8 & 108.8 \\
\hline Water & 272 & 272 \\
\hline Steel fiber & 200 & 78 \\
\hline Quartz sand & 1312 & 1312 \\
\hline Superplasticizer & 48 & 48 \\
\hline
\end{tabular}

Although many specimens were tested, to give clear comparison only result of three tested specimens are shown: 1 . specimen with smaller fibers, homogenous and solid, 2. specimen with smaller fibers, homogenous with crack and 3. specimen with larger fibers, homogenous and solid. They are named as given in Table 2. and shownin Fig. 6 and Fig.7.

Table 2. Specimenslabel

\begin{tabular}{|c|c|c|}
\hline Mixture label & CM1 & \multirow{2}{*}{ CM2 } \\
\hline \multirow{2}{*}{ Specimen label } & $3 \mathrm{~A}$ & \multirow{2}{*}{ SK-2 } \\
\cline { 2 - 3 } & $3 \mathrm{C}$ & \\
\hline
\end{tabular}

\subsection{Test procedure}

On the impact hammer different tip can be mounted, i.e. with different mass and stiffness. After preliminary testing it is decided that hard rubber impact tip should be used [4][3]. The test setup consists of impact hammer (noted as 1 in Fig.4), specimen with attached accelerometers (noted as 2 in Fig.4), data acquisition device (noted as 3 in Fig.4) and computer with commercial or own software for data analysis. The specimen is placed on the soft foam of density $39.64 \mathrm{~kg} / \mathrm{m}^{3}$ in such a way topermit free vibration.

The test is performed in the way of impacting the concrete surface with hammer giving impulse (force) loading to the specimen. The head of impact hammer is equipped with a force sensor in order to measure and register impulse loading, Fig.5. Accelerometers are attached to the top surface of the specimen in fixed points in order to measure the output response. Impacts by the hammer are given at exactly determined points, noted with numbers 6 to 10 in Fig. 2. 


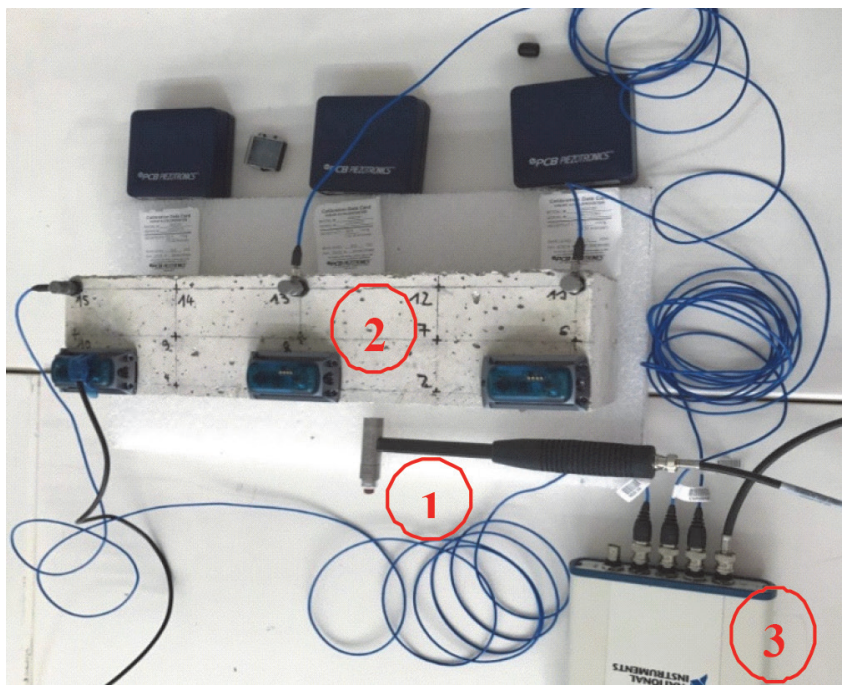

Figure 4. Setup of test for RFM
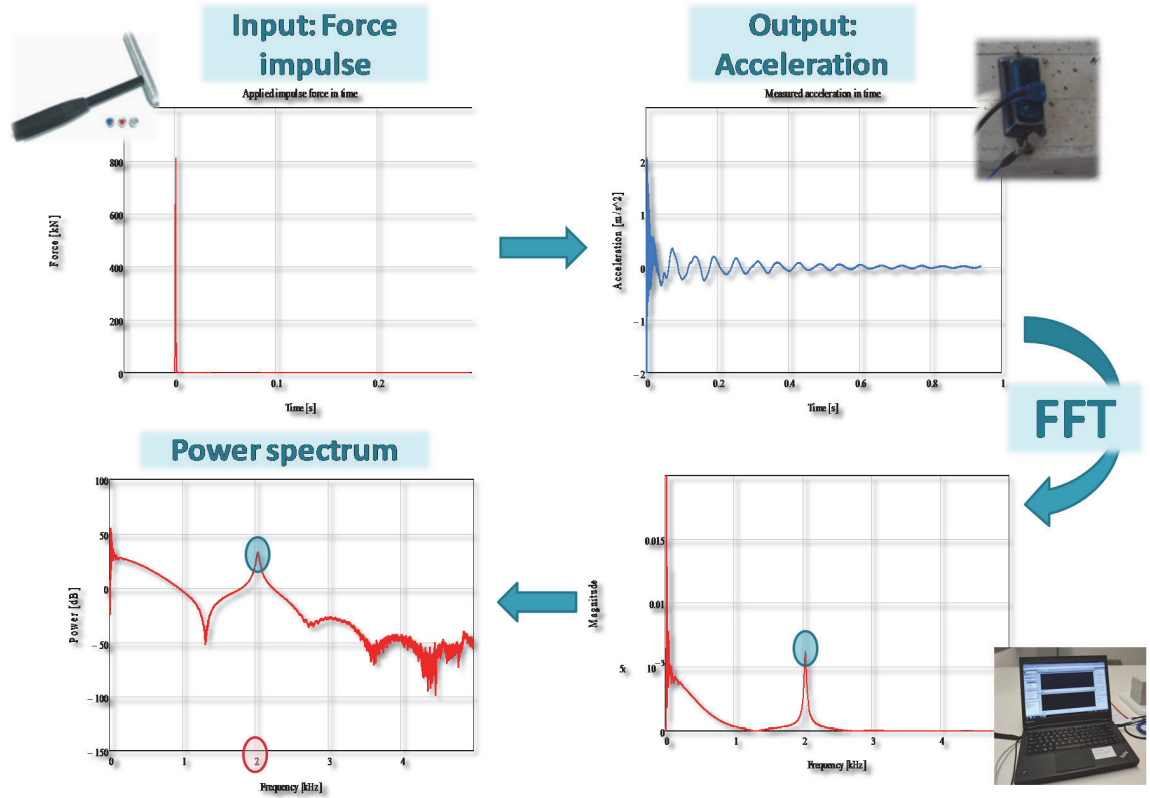

Figure 5. RFM test procedure scheme

Dynamic response in time in the form of acceleration is measured. From time domain, response is transformed into frequency domain with use of fast Fourier transform. Resonant frequency is manifested as a resonant peak in frequency response curve, Fig.5. Based on the theoretical relations between them, modulus of elasticity 
is obtained from fundamental frequency [1]. Dynamic modulus of elasticity is calculated from resonant frequency of specimen before and after damage occurs. Based on the variation of dynamic modulus of elasticity and frequency response curve shape presence of local damage or defect can be determined [5].

\section{Test results}

In Fig. 6-8 frequency response curves together with X-ray scans and photos of specimens are given. $\mathrm{X}$-ray scans are used to verify obtained results and given conclusions, since they give real insight into fiber distribution in each specimen. More about X-ray scans of specimens can be found in [6],[7].

\subsection{Dynamic modulus of elasticity}

Once the fundamental resonant frequency is determined from frequency response curves, Fig. 6 and Fig.7, and knowing specimen dimensions and density, dynamic modulus of elasticity can be easily calculated by using the equations prescribed in standards [8] and [9][8]. Values of calculated dynamic modulus are summarised in Table 3.

Table 3.Dynamic modulus of elasticity

\begin{tabular}{|c|c|c|c|}
\hline Specimen & fr [kHz] & Ed [GPa] ASTM C215 & Ed [GPa] EN 14146 \\
\hline 3A & 1.14 & 27.07 & 28.96 \\
\hline 3C & 1.6 & 27.66 & 29.04 \\
\hline SK-2 & 1.6 & 19.42 & 20.25 \\
\hline
\end{tabular}

\subsection{Result discussion}

First, in Fig. 6 specimens $3 \mathrm{~A}$ and $3 \mathrm{C}$ are shown. Note that main difference is that $3 \mathrm{C}$ is solid and $3 \mathrm{~A}$ is cracked. Further, $3 \mathrm{C}$ is tested with hard impact hammer tip and $3 \mathrm{~A}$ with soft one. It can be noted that in damaged specimen $3 \mathrm{~A}$ resonant frequency is lower than in solid specimen $3 \mathrm{C}$, and consequently dynamic modulus is lower, Table 3. Further, softer tip causes more small peaks in frequency response curve which indicates presence of smaller voids filled with air.

Secondly, in Fig. 7 frequency response curves for specimens 3C (smaller fibers, larger content) and SK-2 (larger fibers, lower content) are given. Note that here both specimens are homogenous and solid. As expected, they have the same resonant frequency, Fig. 7, but because of different density, dynamic modulus of elasticity differs. Namely, specimen with smaller fibers has higher density than specimen with large ones, because smaller fibers are better distributed in concrete, which does 
not contains any air voids, and consequently is less porous. Thus, specimen with smaller fiber has higher elasticity modulus $(29.4 \mathrm{GPa})$ than specimen with larger fibers (20.25 GPa), although as mentioned before resonant frequency is the same for both, Table 3.
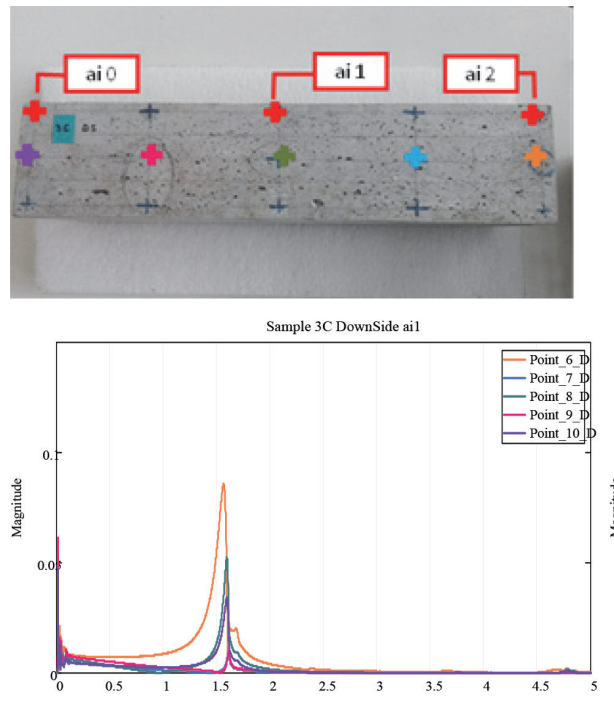

Frequency $[\mathrm{Hz}]$

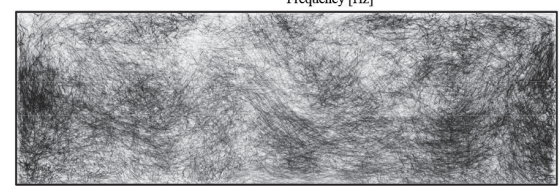

Figure 6. Frequency response and X-ray scan: comparison of specimens $3 \mathrm{C}$ (left) and $3 \mathrm{~A}$ (right)
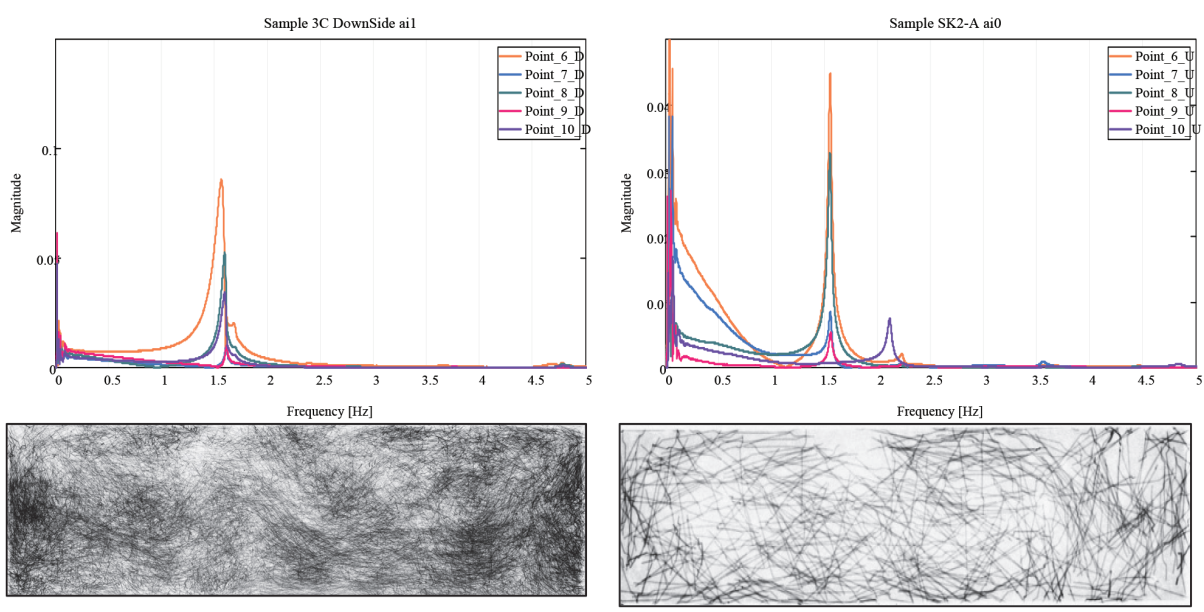

Figure 7. Frequency response and X-ray scan comparison of specimens3C (left) and SK-2 (right) 


\section{Conclusion}

In this work resonant frequency method is used for detection of damage and casting defects in FRC specimens. Dynamic response is measured as acceleration-time curve. Resonant frequency is obtained as resonant peak in frequency response curve. Dynamic modulus of elasticity is calculated from resonant frequency of specimen before and after damage occured. Based on the reduction of dynamic modulus of elasticity and change of frequency response curve some conclusions about damage or defect presence aregiven. With resonant frequency method defects can be detected in such a way that smaller defects (air voids, inhomogeneity) are indicated with change in frequency response curve shape, while larger defects (such as cracks) are indicated with reduction in resonant frequency, and consequently dynamic modulus. Further, it can be concluded that with softer impact hammer tip smaller defects and voids can be detected, while stiffer tip is more convenient for detection of local failures. It is confirmed that resonant frequency method gives accurate values of dynamic modulus. These conclusions are verified by result comparison with $\mathrm{x}$-ray scans of FRC specimens, which give real insight into fiber distribution in each specimen.

Application of the procedure presented in this work is versatile. RFM is used here to assess mechanical properties of FRC concrete and their reduction due to local failure and casting defects. Moreover, RFM can be used to study creep and relaxation of concrete as well as variation in dynamic modulus due to fatigue or cyclic loading. It is applicable for laboratory testing of different concrete mixtures and specimen dimensions as well as in situ measurements for known boundary conditions.

\section{References}

[1] V.M. Malhotra, N.J.Carino, Handbook on nondestructive testing of concrete, 2nd ed., CRC Press, Boca Raton, FL, 2004.

[2] C.Xudong, H.Wanshan, Z.Jikai, Effect of moisture content on compressive and split tensile strength of concrete, IJEMS 19(6) (2012) 427-435.

[3] S. Zulkurnain, H. Meor Othman, Y. Ahmad Shukri, J. Ali, Evaluation of the dynamic modulus of asphalt mixture incorporating reclaimed asphalt pavement, Collections: IJEMS 20(5) (2013) 376-384.

[4] S. Kalinčević, M. Lettich, N. Bede, I. Kožar, Experimental determination of dynamic modulus of elasticity of fiber reinforced concrete, Collection of papers of Faculty of civil engineering in Rijeka, 18 (2015) 45-46.

[5] Y. Lin, M. Sansalone, Detecting flaws in concrete beams and columns using the impact-echo method, ACI MJ, 89(4) (1992) 394. 
[6] N. TorićMalić, N. Bede, I. Kožar, Proc. International Conference on Computational and Experimental Science and Engineering (ICCESEN 2017), 04-08 October, 2017 Antalya-Turkey

[7] S. Kalinčević, Master Thesis, Determination of homogeneity of steel fibres in concrete specimens using computational tomography, Faculty of Civil Engineering in Rijeka, Croatia, 2016.

[8] ASTM C125 Standard Test Method forFundamental Transverse, Longitudinal, andTorsional Resonant Frequencies of ConcreteSpecimens, 2002.

[9] EN 14146. Natural stone test methods- Determination of the dynamic modulus ofelasticity (by measuring the fundamentalresonance frequency), 2004. 